\begin{tabular}{c} 
Volume and Issues Obtainable at Center for Sustainability Research and Consultancy \\
Journal of Business and Social Review in Emerging Economies \\
ISSN: 2519-089X (E): 2519-0326 \\
Volume 3: Issue 2December 2017 \\
CSRᄃ \\
Journal homepage: $\underline{\text { www.publishing.globalcsrc.org/jbsee }}$ \\
\hline
\end{tabular}

\title{
Lessons from the Major Leadership Theories in Comparison to the Competency Theory for Leadership Practice
}

\author{
${ }^{1}$ Chow Tong Wooi, ${ }^{2}$ Lailawati Mohd. Salleh, ${ }^{3}$ Ismi Arif Ismail \\ ${ }^{1}$ Putra Business School, University Putra Malaysia, Malaysia, tongwooi.phd14@grad.putrabs.edu.my \\ ${ }^{2}$ Associate Professor, Faculty of Economics and Management, University Putra Malaysia, \\ Malaysia,lailawati@upm.edu.my. \\ ${ }^{3}$ Associate Professor, Faculty of Education, University Putra Malaysia, Malaysia, ismi@upm.edu.my
}

\begin{tabular}{l}
\hline ARTICLEDETAILS \\
\hline History \\
Revised format: Nov 2017 \\
AvailableOnline: Dec 2017 \\
\hline Keywords \\
Evolution of Leadership \\
Competency Concept \\
Emerging Leadership \\
Competencies \\
Multi-facet \\
Concept Leadership \\
$21^{\text {st } \text { Century-Leadership }}$ \\
\end{tabular}

JEL Classification:

O15, O19

\begin{abstract}
Purpose:This article presents perspectives on the review of eight major theories of leadership in comparison to thecompetency approach. Also, the definitions, significance, and benefits of the leadership competency concept are also highlighted.

Methodology: A review of the various published literature on the major leadership theories, the competency theory, and the related topics on the scope of the study.

Results: The findings of the review show the significance and relevance of the leadership competency approach as a viable leadership option for the $21^{\text {st }}$ century- leadership. Leadership for best practice continues to evolve due to the changing leadership landscape. The literature states that newer theories will eventually replace old leadership concepts.

Implications: An understanding of the various leadership theories, specifically the competency theory will facilitate in the choice of the adoption of leadership approach. Moreover, employing the appropriate leadership practice in this current knowledge-based era is key to individual and organizational performance.
\end{abstract}

(C) 2017 The authors, under a Creative Commons AttributionNonCommercial 4.0

Corresponding Author's Email Address: tongwooi.phd14@grad.putrabs.edu.my

Recommended Citation:Chow, T.W.,Salleh,L.M.\& Ismail,I.A., (2017). Lessons from Major Leadership Theories in comparison to the Competency Theory for Leadership Practice.Journal of Business and Social Review in Emerging Economies.3(2) 147-156. DOI:https://doi.org/10.26710/jbsee.v3i2.86

\section{Introduction}

Interest in leadership study has gained popularity in the last three decades, though there was evidence of the practice of leadership since the early civilization (Goffee\& Jones, 2000). Leadership plays an important part in the progress and achievement of societies, organizations, and politics (Howell \& Costly, 2006; McCallum \& O'Connell, 2009). Literature suggests that leadership has an impact on an organization's performance (McDermott, Kidney, \& Flood, 2011; Yuen \& Lee, 2011). However, theleadership literature continues to develop due to contributing factors such as contexts, contextualization, and the expectations of leadership (Ivancevich, Konopaske, \& Matteson, 2014; Van Wart, 2013).

The overview descriptions of the various major leadership theories offer insights on how leadership concepts serve as the underpinning foundation for leadership approaches. It is hoped that this paper will help the reader to recognize the contribution of the leadership competency concept for effective leadership 
practice. This article sheds light on the significance and relevance, of the leadership competency theory as a guiding framework to leadership study and practice. Also, this paper proposes the development of the multi-facet concept of leadership.

The article outlines four main points. The first point briefly introduces and describes the development of the leadership. In point two, the eight major leadership theories are presented. Then, in point three, the background, definitions, and the leadership competency theory is discussed, and the evolution of leadership (Figure 1). Point four is the conclusion and implication. Lastly, point five is the recommendations.

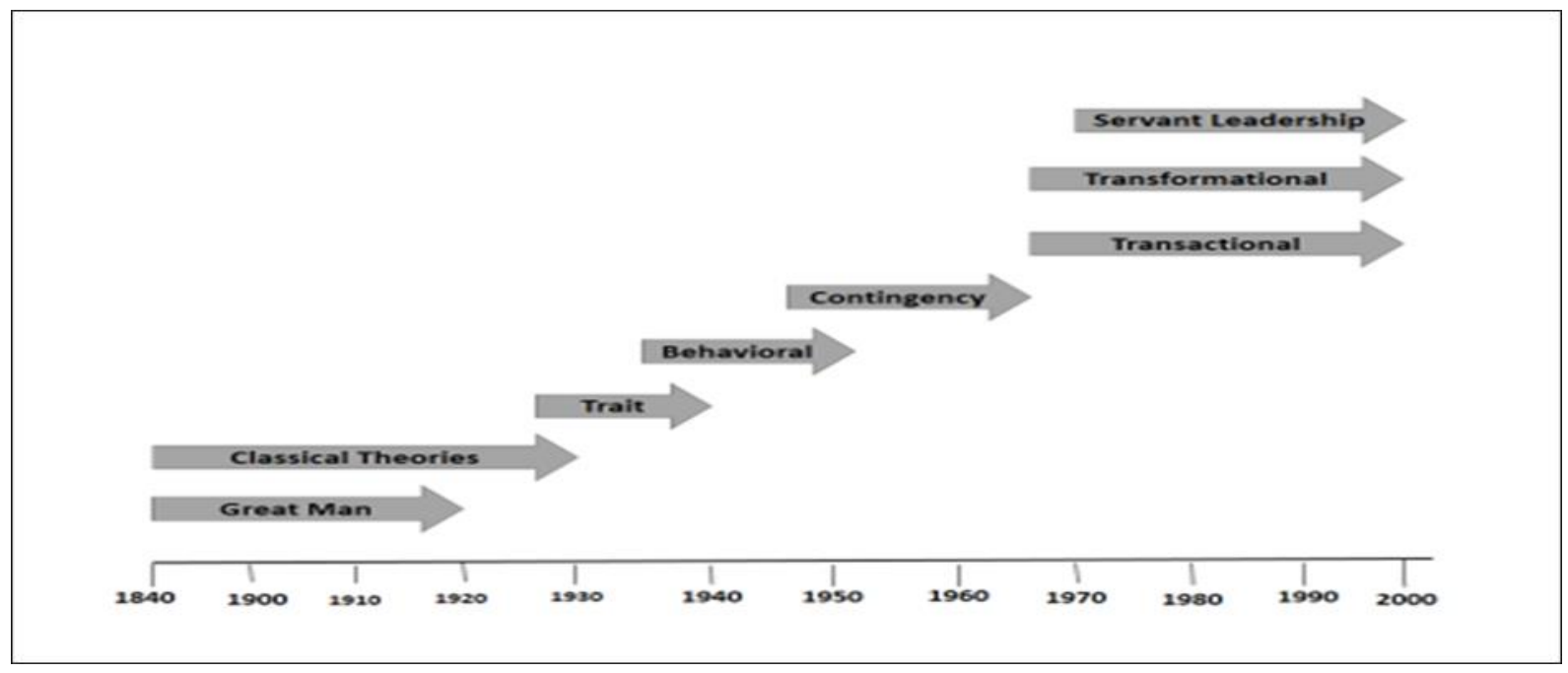

\section{Figure 1: The evolution of leadership theory Source: Relevant literature reviewed.}

\section{Review of major leadership theories}

Literature review shows that there are various ways of approaching the study of the complexities of leadership. The leadership field can be addressed from the different theoretical perspectives such as models, tools, paradigms, frameworks, and influential thinkers (Ulrich, 2010). Dinh et al., (2014) in their research on the current theoretical trends in the new millennium identified a total of 67 theories, of which 41 are established theories, and 26 are emerging theories. One of the ways to study about leadership is through learning about the major leadership theories.

The discussions on the overview of leadership theories in this paper cover eight main theories of leadership, that is, great man theory, the classical theories, the trait theory, the behavioural theory, the contingency theory, the transactional leadership theory, transformational leadership theory, and servant leadership theory (Figure 1). The development of the leadership theories was not straight forward, there were overlapped in time frame.

\subsection{Great man theory}

The emergence of the theory of the great man is traced to the mid- $19^{\text {th }}$ century. Historian Thomas Carlyle popularized the concept, which espoused that leaders are born with leadership characteristics as compared to non-leaders (Chemers, 2000; Kirkpatrick \& Locke, 1991). The underlying assumption of the great man theory is that leadership traits were inherited particularly by those from the elite or upper society. In short, great leaders were born with leadership qualities, but not developed. There is limitation of the great man theory as very few are born with leadership abilities. Leadership researchers such as Bolden, Gosling, Marturano, \& Dennison, (2003), Ralph Stogdill (1948), and Van Seters and Field (1990), concluded that personality is not a determining factor in the eligibility for leadership. 


\subsection{Classical theories}

In the subsequent years, during the Industrial Revolution period, the classical theories of leadership emerged due to management dilemmas. It was a time for management and organizational change. The three most important classical leadership approaches were the administrative theory, the bureaucratic management, and the scientific management (Cole \& Kelly, 2011; Schermerhorn, 2011).

Scientific management was first initiated by Frederick W. Taylor (1856-1915) which focus on the scientific way to study management. The scientific management emphasised on efficient job performance. Taylor tested the concept of time study to find effective ways of performing the required tasks. Henry Fayol (1842-1925), a management theorist promoted and developed the theory of management. He identifies and helps systematize the principles of administrative and managerial prescriptions (Golden Pryor \&Taneja, 2010). The administrative theory focuses on the total organization instead of the individual. Fayol highlighted the management principles of planning, organizing, leading, and controlling. Max Weber (1864-1920), a sociologist and political economist, developed the bureaucratic management theory. The bureaucratic management emphasised the scientific approach to study management. The principles of the bureaucratic type of formal organization and administration emphasised on efficiency and effectiveness. The bureaucratic organization employs rules, hierarchy, the division of labour and procedures as a guide to worker's behaviours. These classical theories form the foundation to many subsequent leadership and management studies.

\subsection{Trait theory}

The trait theory developed from the great man theory. However, the trait theory is more systematised in its approach in evaluating the leaders. The trait theory did not assume that leadership traits were inherited, but instead highlighted that the leaders' characteristics are distinguishable from non-leaders (Kirkpatrick \& Locke, 1991). Traits were primarily referred to as human attributes. The core focus of the trait theory is on human personality and characteristics such as physical, intellectual, and social, traits in distinguishing leaders from followers. Good leadership is not necessarily associated with traits (Bolden et al. 2003; Van Seters\& Field, 1990). The trait research over the century resulted in these major leadership traits that are intelligence, self-confidence, determination, integrity, and sociability. These findings have contributed to leadership.

\subsection{Behavioural theories}

The behavioural theories advocated the importance of human relationships. In the behavioural approach, researchers investigated on the idea how a leader's behaviour affects their effectiveness and followers. The behavioural models were influenced by Douglas McGregor writings that focus on the place of the role of behaviours of leaders (Bolden et al., 2003). The theory is also referred to like the style approach which emphasises on the leader's behaviour and action. The three most important styles described in leadership literature are autocratic, democratic, and leissez-faire. The behavioural approach implies that leaders tend to use one style. The core assumption of the theory is that leaders are made rather than born which implies that leaders can be trained (made) (Ayman \&Korabik, 2010).

\subsection{Contingency theory}

The contingency theory is attributed to the writings of Fred Edward Fiedler (Verkerk, 1990). The theory is also known as the leader-match theory. According to Fiedler, the group performance is contingent on the leader using the suitable style in consideration of the organizational situation favourableness (Fiedler, 1971). The fundamental emphasis of the contingency theory is that effective leadership behaviour depends on situational factors. The theory assumes that active leadership style must consider the particular situation to achieve the desired results. Hence, for a leader to be productive, there needs to be a match between the leader's approach and the situation at hand. The contingency theory also suggests that there is no one best approaches to leadership. 


\subsection{Transactional leadership theory}

The primary main contributors to the transactional leadership theory have been credited to James Macgregor Burns and Bernard M. Bass (Yahaya\&Ebrahim, 2016). The main idea of the transactional leadership theory essentially described the mutual exchange of the leader and the follower to achieve the goal (Muijs, 2011). The theory values a two way beneficial relationship between the leaders and followers. The underlying assumption is that reward and punishment motivate people. It uses the incentive and reward factors to obtain results. The theory tends to be goal oriented and does not emphasise on employee personal development.

\subsection{Transformational leadership theory}

Transformational leadershiphas been classified as one of the newer leadership paradigms. The transformational leadership is founded by James Macgregor Burn (1978) but further developed by Bass (1985) and also advanced by Bass and Avolio (1994). Burns (1978) defines transformational leadership as "leaders and followers raise one another to higher levels of morality and motivation" ( $p$. 20).Transformational leadership essentially is about the process of transformation and change involving the individuals and organizations through long-term goals (Bass \&Riggio, 2006, Muijs, 2011). The significance of the theory is due to its focus on the motivation and concern for the followers. Burns argued that real leadership achieves the goal and changes people for the better at the same time (Covey, 2007). The theory has evolved into a dominant leadership perspective in the last 20 years (Black, 2015).

\subsection{Servant leadership theory}

The concept of servant leadership essentially combined the concepts of servant hood and leadership. The servant leadership theory emphasised that leaders must serve first and not lead first. Robert K. Greenleaf has been credited for initiating the concept of servant leadership in modern organizations. The theory emphasises on the kind of leadership that transcend self-interest to serve others. The theory emphasizes on virtues such as patience, kindness, humility, respectfulness, honesty, and commitment. Stone, Russell, and Patterson (2004) postulate that as servant leadership theory gain support, historically, the concept has not been systematically defined, and research is still relatively in its early stage. However, there are researchers who has vouched for the servant leadership as a valid theory (Washington, 2007).

In summary, these are the evolution of the main leadership theories that emerged over a period of a century (Figure 1). A related point raised by Stone and Patterson (2005) in their study, which is based on Kuhn's concept, posits that when the existing theory fails to explain a phenomenon, a new theory emerges. When an existing theory is not able to sufficiently account for a phenomenon, the newer theories will eventually replace the older theories (Pisapia, 2009; Yammarino, 2013).

\section{Leadership competency theory}

\subsection{Background of the competency movement}

The study on competency has been credited to David McClelland, a Harvard University professor in the United States. McClelland challenges the traditional idea of evaluating individual capabilities by emphasizing on intelligence. He proposes that job performance has to do with the competencies. McClelland stressed that the underpinning essential competency results in superior performance. Furthermore, the development of the concept of skills has been linked to the earlier research on skill by Katz (1974). Katz emphasised the importance of skills for job performance. His classic work introduced the three sets of skills which are: technical, human, and conceptual skills. His writings raised the importance of identifying the right skills for job performance.

Review of literature has shown that leadership researchers recognize the relevance of the competency approach (Black, 2015; Muller \& Turner, 2010; Northouse, 2013). Dinh et al. (2014) in their research on leadership theory classifies the leadership competency as an established theory. The competency approach built on the research work on skills, abilities, and cognitive intelligence (Boyatzis, 2008, 2009). 
Leadership researchers are suggesting that there is enough evidence to argue that the competency concept forms the basis for effective individual and organizational performance (Black, 2015; Intagliata, Ulrich, \& Smallwood, 2000; Sutton \& Watson, 2013; Vazirani, 2010). Leadership skill is a major contributing factor in the $21^{\text {st }}$ century-work place (De Beeck\&Hondeghem, 2009; O’Connell, 2014).

\subsection{Definitions of the competency concept}

The term competence, competency, and skills have been used interchangeably in the literature. Most definitions of competence and competency include skills. The understanding of these definitions facilitates in understanding the foundational concept of leadership competencies. The term competency has evolved into a multi-facet concept (Hoffman, 1999). The word was first used in the education field, but Boyatzis (1982) popularized it in the management area. Boyatzis (1982) defines competency as "An underlying characteristic of a person in that it may be a motive, trait, aspect of one's self-image or social role, or a body of knowledge which he or she uses" (p. 21), while Sutton and Watson (2013) states, "Competencies are defined as a capability or ability" (p. 1024). Some researchers such as Athey and Orth (1999), posit that it is likely that the definitions of competency will evolve.

\subsection{The competency theory}

Researchers have acknowledged the significance of the leadership competency concept for individual and organizational performance (Allio, 2005; Gonin, Napiersky, \&Thorsell, 2011). In the 1990s, competencies theorists such as Mumford and his colleagues published a series of studies promoting the skills-based model to solve organizational issues (Mumford, Zaccaro, Harding, Jacobs, \& Fleishman, 2000a; Yammarino, 2000). Skill-based models, known as the capability model developed on and reinforced Katz's skill, leadership concept (Mumford, Zaccaro, Connely, \& Marks, 2000b; Mumford et al., 2000b). The study also shows that effective leadership involves capabilities, knowledge, and expertise. Mumford and co-researchers in their study of the skills-based framework of leadership suggest that the skills-based concept is a viable leadership approach for the 21 st century-knowledge-based organizations (Mumford et al., 2000b; Yammarino, 2000). The leadership competency concept is said to encompass the many intricacies of leadership (Muller \& Turner, 2010; Northouse, 2013). The focus on competency can provide the key to strategic advantage in light of the competitive environment (Cardy\&Selvarajan, 2006).

There are various benefits of the leadership competency concept. The driver of the quality of leadership has been linked to competencies (Boatman \&Wellings, 2011; Liak, T. K, 2010). Furthermore, writers such as Intagliata et al., (2000) states that the competency concept can be leveraged on, to build a leadership brand. Higgs (2003) has proposed that leadership competencies need to be complemented by personal characteristics such as authenticity, integrity, will, self-belief, and self-awareness.

The strength of the competency concept includes the idea that leadership capabilities can be learned, developed, coached, and trained beside experience (Dinh et al., 2014; Lussier\&Achua, 2016; Yammarino, 2013). Education also enhances leadership competencies (Delia Davila Quintana, Ruiz, \& Vila, 2014). Individuals can identify their developmental needs which indirectly lead to the success of the organization they work in (Delia Davila Quintana et al., 2014 James, 2011). Northouse (2013) asserts that the competencies approach will be used in the future leadership development. Based on reports in organizational leadership, the two main strengths of the competency approach are the flexibility and uniqueness of the concept to suit the organizational needs (Bolden et al., 2003). However, it is preferable for competencies to be oriented towards the future. Besides, researchers stressed that the competency approach needs to be realigned to the strategies, goals, capabilities, and values of the organizations, so as to contribute towards optimal effectiveness (Cardy\&Selvarajan, 2006).

Leadership theorists are postulating that future research on leadership is converging towards an integrative perspective era (Avolio, 2007; O’Connell, 2014; Van Seters\& Field, 1990). Essentially, an 
integrative framework combines the different leadership ideas to form one comprehensive leadership construct. The literature has postulated on the emerging or future leadership competencies which are based on the leadership competency theory. Organizations such as OECD and Institute for the Future in the US discussed on identifying the future competencies and future work skills 2020, required by leaders respectively (De Beeck\&Hondeghem, 2009; Future Work Skills 2020, 2011). Due to the evolvement of the global business environment, organizations of the 21st century require leaders with new emerging leadership competencies or the combination of skills (Bennett \&Lemoine, 2014; Black, 2015; Dinh et al., 2014; Van Wart, 2013).

A multi-faceted globalised environment requires a multi-facet concept approach to leadership (Black, Groombridge, \& Jones, 2013; Pisapia, 2009). The 21st century-leaders need many leadership competencies due to the evolving trends of the leadership paradigms. The conceptualization of new leadership frameworks is inevitable for the new era leadership reality (Pisapia, Reyes-Guerra, \&CoukosSemmel, 2005; Pisapia, 2009). As in any improvement process, leadership theories should be reviewed progressively to ensure that the management of leadership remains in tandem with the times and bear results (Bolden et al., 2003).

\section{Conclusion and implications}

As discussed in this paper, leadership theories evolved due to changes in the environment. In looking at the evolution of leadership theory, the trend does indicate that new leadership concepts emerge. As highlighted, the emergence of new leadership framework is inevitable. The leadership competency theorists have proposed the competency concept as a viable option for leadership performance for the $21^{\text {st }}$ century-leadership. Organizations of the $21^{\text {st }}$ century need leaders with emerging leadership competencies or combination of relevant skills. The implication for research can include innovative ways of conceptualizing leadership development based on the leadership competency concept due to the flexibility of the concept. The conceptualization of leadership development should also include the combination of emerging leadership competencies or the multi-facet leadership concept. Leadership theory and practice need to remain current and dynamic, so as to be effective.

\section{Recommendations}

Future direction for research should consider integrating key emerging leadership competencies for the development of leadership construct depending on the organizational context. Some of the proposed emerging leadership competencies are leadership agility, visioning and strategic thinking, adaptability and change, relationship and collaboration, corporate leadership, and generating funds. The emerging leadership constructs forms the proposed multi-facet leadership concept.

\section{Acknowledgement:}

With due recognition, we wish to acknowledge the contribution and efforts of Dr. ArisArifMundayat (Faculty of Defence Strategy, Indonesia Defence University) and the late Prof. Dr. Abu DaudSilong (formerly from the Faculty of Education, University Putra Malaysia).

\section{References}

Allio, R. J. (2005). Leadership development: teaching versus learning. Management Decision, 43 (7/8),1071-1077.

Athey, T. R., \& Orth, M. S. (1999). Emerging competency methods for the future.Human resourcemanagement, 38(3), 215-225.

Avolio, B. J. (2007). Promoting more integrative strategies for leadership theory-building. American Psychologist, 62 (1), 25.

Ayman, R \&Korabik, K 2010. Leadership: why gender and culture matter. American Psychologist, 65, (3), 157-70.

Bass, B. M. \&Riggio, R. E. (2006), Transformational Leadership, Mahwah, NJ: Lawrence Erlbaum Associates. 
Bennett, N., \&Lemoine, G. J. (2014). What a difference a word makes: Understanding threats to performance in a VUCA world. Business Horizons, 57 (3), 311-317.

Black, S. A., Groombridge, J. J., \& Jones, C. G. (2013).Using better management thinking to improveconservation effectiveness. ISRN Biodiversity, 2013.

Black, S. A. (2015). Qualities of effective leadership in higher education.Open Journal of Leadership,4 (02), 54.

Boatman, J., \&Wellins, R. S. (2011).Global leadership forecast 2011: time for a leadership revolution. Bridgeville, PA: Development Dimensions International.

Bolden, R., Gosling, J., Marturano, A., \& Dennison, P. (2003). A review of leadership theory and competency frameworks. Centre for Leadership Studies, University of Exeter. UK.

Boyatzis. R. E. (1982). The competent manager: A model for effective performance. New York: NY: John Wiley \& Sons.

Boyatzis, R. E. (2008). Competencies in the 21st century.Journal of management development, 27 (1), 5-12.

Boyatzis, R. E. (2009). Competencies as a behavioural approach to emotional intelligence.Journal of Management Development, 28 (9), 749-770.

Burns, J. M. (1978). Leadership. New York. NY: Harper and Row Publishers.

Cardy, R. L., \&Selvarajan, T. T. (2006). Competencies: Alternative frameworks for competitive advantage. Business Horizons, 49 (3), 235-245.

Chemers, M. M. (2000). Leadership research and theory: A functional integration. Group Dynamics: Theory, research, and practice, 4 (1), 27.

Cole, G. A., \& Kelly, P. (2011). Management theory and practice ( $\left.7^{\text {th }} E d\right)$. Hamshire, UK: SouthWestern Cengage Learning.

Covey, S. (2007).The transformational leadership report. Retrieved February 1 $1^{\text {st }}, 2017$ from www.transformationalleadership.net/products/TransformationalLeadershipReport.pdf

De Beeck, S. O. \&Hondeghem, A. (2009).Managing competencies in government: state of the art practices and issues at stake for the future. Paris: OECD Conference Centre.

Delia Davila Quintana, C., Mora Ruiz, J. G., \& E. Vila, L. (2014).Competencies which shape leadership.International Journal of Manpower, 35 (4), 514-535.

Dinh, J. E., Lord, R. G., Gardner, W. L., Meuser, J. D., Liden, R. C., \& Hu, J. (2014). Leadership theory and research in the new millennium: Current theoretical trends and changing perspectives. Leadership Quarterly, 25 (1), 36-62. Doi:10.1016/j.leaqua.2013.11.005

Fiedler, F. E. (1971). Validation and extension of the contingency model of leadership effectiveness: A review of empirical findings. Psychological bulletin, 76 (2), 128.

Future Work Skills 2020 (Executive Summary). (2011). Institute for the Future. Retrieved January 5th, 2017 from http://www.iftf.org

Goffee, R., \& Jones, G. (2000). Why should anyone be led by you? Harvard Business Review, September-October, pp. 63-70.

Golden Pryor, M., \&Taneja, S. (2010).Henri Fayol, practitioner and theoretician-revered and reviled.Journal of Management History, 16 (4), 489-503.

Gonin, D., Napiersky, U., \&Thorsell, J. (2011).Innovation in leadership development.Advances in Global leadership, 6, 155-214. 
Higgs, M. (2003). How can we make sense of leadership in the 21 st century? Leadership \& organization development journal, 24 (5), 273-284.

Hoffman, T. (1999). The meanings of competency. Journal of European Industrial Training, 23 (6), 275-286.

Howell, J. P. \& Costley, D. L. (2006), Understanding Behaviours for effective leadership, Upper Saddle River, NJ: Prentice Hall.

Intagliata, J., Ulrich, D., \& Smallwood, N. (2000). Leveraging leadership competencies to produce leadership brand: Creating distinctiveness by focusing on strategy and results. People and Strategy, 23 (3), 12.

Ivancevich, J. M., Konopaske, R., \& Matteson, M. T. (2014).Organizational behaviour and management. New York, NY: McGraw- nHill/Irwin, c2014.

James, K. T., (2011). Leadership in context. Retrieved November 12th, 2016 from www.kingsfund.org.uk/... /Leadership-in-context-leadership-t

Katz, R. L. (1974). Skills of an effective administrator.Harvard Business Review, 33 (1), 33-42.

Kirkpatrick, S. A. \& Locke, E. A. (1991), Leadership: Do Traits Matter? The Executive, 5 (2), 48-60.

Liak, T.K., (2010). Leadership challenges in the transformation of healthcare. In Ulrich, D. (Ed). Leadership in Asia: challenges and opportunities. Singapore: McGraw Hill.

Lussier, R., \&Achua, C. (2016).Leadership: Theory, application, and skill development $\left(6^{\text {th }}\right.$ $E d)$. Boston, MA: Cengage Learning.

McCallum, S., \& O'Connell, D. (2009). Social capital and leadership development: Building stronger leadership through enhanced relational skills. Leadership \& OrganizationDevelopment Journal, 30 (2), 152-166.

McDermott, A., Kidney, R., \& Flood, P. (2011). Understanding leader development: Learning from leaders. Leadership and Organization Development Journal, 32 (4), 358-3.

Muijs, D. (2011). Leadership and organisational performance: from research to prescription? International Journal of Educational Management, $25 \quad$ (1), 45-60. DOI http://dx.doi.org/10.1108/09513541111100116

Müller, R., \& Turner, R. (2010). Leadership competency profiles of successful project managers. International Journal of Project Management, 28 (5), 437-448.

Mumford, M. D., Zaccaro, S. J., Harding, F. D., Jacobs, T. O., \& Fleishman, E. A. (2000a). Leadershipskills for a changing world: solving complex social problems. The Leadership Quarterly, 11(1), 11-35.

Mumford, M. D., Zaccaro, S. J. Connely, M. \& Marks. M. A. (2000b). Leadership skills, conclusions, and future directions.The Leadership Quarterly, 11 (1), 155.

Northouse, P. G., (Ed.). (2013). Leadership: Theory and practice. Thousand Oaks, CA: Sage publications.

O'Connell, P. K. (2014). A simplified framework for 21st century leader development.The LeadershipQuarterly. 25 (2), 183-203, Doi: 10.1016/j.leaqua.2013.06.001.

Pisapia, J., Reyes-Guerra, D., \&Coukos-Semmel, E. (2005).Developing the leader's strategic mindset: establishing the measures. Leadership review, 5 (1), 41-68.

Pisapia, J. (2009). The strategic leader: new tactics for a globalizing world. Charlotte, NC: InformationAge Publishing.

Schermerhorn, J.R. (2011). Introduction to Management. Hoboken, NJ: John Wiley \& Sons.

Stogdill, R. M. (1948). Personal factors associated with leadership: a survey of the literature. The Journal of Psychology, 25 (1), 35-71.

Stone, A. G., Russell, R. F., \& Patterson, K. (2004). Transformational versus servant leadership: a difference in leader focus.Leadership \&Organization Development Journal, 25 (4), 349-361.

Stone, A. G., \& Patterson, K. (2005).The history of leadership focus.Servant leadership research roundtable proceedings.School of Leadership Studies, Regent University, Virginia Beach, US. 
Sutton, A., \& Watson, S. (2013). Can competencies at selection predict performance and developmentneeds? Journal of Management Development, 32 (9), 1023-1035.

Ulrich, D. (2010). Leadership in Asia: Challenges and opportunities. Singapore: McGraw Hill.

Van Seters, D. A., \& Field, R. H. (1990). The evolution of leadership theory.Journal of Organizational Change Management, 3 (3), 29-45.

Van Wart, M. (2013).Lessons from leadership theory and the contemporary challenges ofleaders. Public Administration Review, 73 (4), 553-565.

Vazirani, N. (2010). Competencies and competency model-a brief overview of its development and application. SIES Journal of Management, 7(1), 121.

Verkerk, P. (1990). Fiedler's contingency model of leadership effectiveness: background and recent developments. Department of Philosophy and Social Sciences, Eindhoven University ofTechnology.

Washington, R. R. (2007). Empirical relationships between theories of servant, transformational, and transactional leadership. In Academy Of Management Proceedings, 2007 (1), 1-6, Academy of Management.

Yahaya, R., \&Ebrahim, F. A. (2016). Leadership styles and organizational commitment: literature review. Journal of Management Development, 35(2).

Yammarino, F. J. (2000). Leadership skills: Introduction and overview. The leadership quarterly, 11(1), 5-9.

Yammarino, Y. (2013). Leadership: past, present, and future. Journal of Leadership \& OrganizationalStudies, 20: 149. Doi: 10.1177/1548051812471559

Yuan, C. K., \& Lee, C. Y. (2011). Exploration of a construct model linking leadership types, organization culture, employees performance and leadership performance. Procedia Social and Behavioural Sciences, 25, 123-136. 
